\title{
Analisis Pengaruh Good Corporate Governance Dan Profitabilitas Terhadap Nilai Perusahaan Pada Bank Swasta Devisa Nasional Yang Terdaftar Di Bursa Efek Indonesia (BEI) Tahun 2015-2019
}

\author{
Wiwin Indah Sari $^{\mathrm{a}}$, Haifah ${ }^{\mathrm{b}}$, Wiwik Fitria Ningsih ${ }^{\mathrm{c}}$ \\ ${ }^{a}$ Mahasiswa STIE Mandala \\ ${ }^{b}$ Dosen STIE Mandala, haifah@stie-mandala.ac.id \\ c Dosen STIE Mandala,wiwik@stie-mandala.ac.id
}

\section{N F O A R T I K E L}

Riwayat Artikel:

19 Januari 2021

02 Februari 2021

01 April 2021

Keywords:

Good Corporate Governance, Board of Commissioners, Board of Directors, Audit Committee, Profitability, and Company Value

Kata Kunci:

Good Corporate Governance, Dewan Komisaris, Dewan Direksi, Komite Audit, Profitabilitas, dan Nilai perusahaan

\begin{abstract}
A B S T R A C T
This study aims to analyze the effect of good corporate governance and profitability on firm value in National Private Foreign Exchange Banks listed on the Indonesia Stock Exchange (IDX) for the 20152019 period. Good corporate governance variable is proxied by the board of commissioners, board of directors, and audit committee, while profitability is proxied by net profit margin (NPM). The research sample was selected based on purposive sampling technique, so as to obtain a sample of 14 national foreign exchange private banks. The analytical method used is multiple regression analysis. The results showed that partially the board of commissioners, board of directors, audit committee, and profitability had no significant effect on firm value. Simultaneously, all the independent variables, namely the board of commissioners, the board of directors, the audit committee, and profitability have a significant effect on firm value.
\end{abstract}

\section{A B S T R A K}

Penelitian ini bertujuan untuk menganalisiss pengaruh good corporate governance dan profitabilitas terhadap nilai perusahaan pada Bank Swasta Devisa Nasional yang terdaftar di Bursa Efek Indonesia (BEI) periode 2015-2019. Variabel good corporate governance di proksikan oleh dewan komisaris, dewan direksi, dan komite audit, sedangkan profitabilitas di proksikan oleh net profit margin (NPM). Sampel penelitian dipilih berdasarkan teknik purposive sampling, sehingga diperoleh sampel sebanyak 14 bank swasta devisa nasional. Metode analisis yang digunakan adalah 
analisis regresi berganda. Hasil penelitian menunjukkan bahwa secara parsial dewan komisaris, dewan direksi, komite audit, dan profitabilitas tidak berpengaruh signifikan terhadap nilai perusahaan. Secara simultan, semua variabel idependen yaitu dewan komisaris, dewan direksi, komite audit, dan profitabilitas berpengaruh signifikan terhadap nilai perusahaan.

\section{PENDAHULUAN}

Pertumbuhan usaha saat ini di Indonesia semakin meningkat, hal ini dapat dilihat dari tingkat perekonomian Indonesia triwulan pada II-2020 terhadap triwulan II-2019 mengalami kontraksi pertumbuhan sebesar 5,32 persen (Badan Pusat Statistik, 2020). Meningkatnya perekonomian Indonesia tentunya akan menciptakan persaingan pasar yang semakin ketat, mengharuskan perusahaanperusahaan mengelola perusahaannya dengan professional. Demikian pula investor dalam mencari alternatif untuk berinvestasi, selalu mencari perusahaan yang dikelola dengan professional (Akal Muhammad dan Akal Andi, 2015:1). Perusahaan mempunyai berbagai tujuan salah satunya memaksimalkan kesejahteraan pemilik perusahaan dengan menciptakan nilai untuk para pemilik saham (Syaifuddin, 2008:6).

Nilai perusahaan dapat dipengaruhi oleh beberapa aspek, salah satunya adalah tingkat profitabilitas dan aspek good corporate governance. Menurut Signaling Theory profitabilitas yang tinggi dapat menunjukkan prospek perusahaan yang bagus, sehingga investor akan merespon positif dan nilai perusahaan akan meningkat (Febrianti, 2012:152). Hasil penelitian Sugiyanto dan Setiawan (2019:472) menunjukkan profitabilitas berpengaruh signifikan terhadap nilai perusahaan, hal ini membuktikan bahwa memang perusahaan yang memiliki tingkat profitabilitas yang tinggi akan lebih mudah untuk menarik investor.

Menurut Cadbury Committee, Good Corporate Governance adalah seperangkat aturan yang merumuskan hubungan antara para pemegang saham, manajer, kreditor, pemerintah, karyawan, dan pihak-pihak yang berkepentingan lainnya baik internal maupun eksternal sehubungan dengan hak-hak dan tanggung jawab mereka. Good corporate governance menciptakan nilai tambah bagi semua pihak yang berkepentingan (stakeholders). Secara teoritis, pelaksanaan good corporate governance dapat meningkatkan nilai perusahaan, dengan meningkatkan kinerja keuangan mereka, mengurangi risiko yang mungkin dilakukan oleh dewan komisaris dengan keputusan-keputusan yang menguntungkan diri sendiri dan umumnya good corporate governance 
dapat meningkatkan kepercayaan investor (Akal Muhammad dan Akal Andi, 2015:2).

Hasil penelitian Susanto dan Juniarti (2013:246) good corporate governance memiliki pengaruh yang positif dan signifikan terhadap nilai perusahaan yang terdaftar di BEI. Dari hasil ini menunjukkan dengan meningkatnya good corporate governance maka juga dapat meningkatkan nilai perusahaan secara signifikan.Untuk mendukung terlaksananya GCG penting adanya mekanisme perusahaan yang akan menjalankan fungsinya sesuai ketentuan dan melaksanakan tugas serta tanggung jawabnya untuk kepentingan perusahaan. Mekanisme perusahaan yang membantu terwujudnya corporate governance tersebut terdiri dari Dewan Komisaris, Dewan Direksi, dan Komite Audit. Dengan dibentuknya mekanisme seperti ini diharapkan nantinya tidak ada satu pihak manapun yang diuntungkan maupun dirugikan.

Perbankan merupakan lembaga keuangan yang sangat penting dalam mendorong pertumbuhan ekonomi, salah satu peran utama perbankan sebagai lembaga yang menghubungkan pihak investor dengan pihak kreditor, sehingga dapat mendorong alokasi sumber daya ekonomi menjadi lebih efektif. Perusahaan yang bergerak dalam sektor perbankan banyak berhubungan dengan masyarakat, perusahaan yang banyak berhubungan dengan masyarakat akan sangat mementingkan citra atau nilai perusahaan. Jika dilihat berdasarkan kepemilikan modalnya bank umum dikelompokkan menjadi 6 jenis yakni Bank Persero, Bank Umum Swasta Devisa Nasional, Bank Umum Swasta Nasional Non Devisa, Bank Pembangunan Daerah, Bank Campuran, dan Bank Asing. Banyaknya jenis bank yang ada di Indonesia serta sektor perbankan yang pada dasarnya banyak berhubungan dengan masyarakat tentunya bank-bank terserbut akan berlomba-lomba untuk meningkatkan kualitas dengan meningkatkan nilai perusahaannya untuk menarik investor.

Objek penelitian yang di ambil dalam penelitian ini adalah Bank Swasta Devisa Nasional. Bank Swasta Devisa Nasional dalam kurun waktu 2015-2019 menujukkan kinerja yang progresif ditunjukkan dengan laba perusahaan yang setiap tahunnya meningkat, hal tersebut dapat dilihat dalam tabel dibawah ini:

Tabel 1 Profit Bank Swasta Devisa Nasional 2015-2019

\begin{tabular}{|c|c|}
\hline Tahun & Laba \\
\hline 2015 & 29,1 Triliun \\
\hline 2016 & 31,2 Triliun \\
\hline 2017 & 42,4 Triliun \\
\hline 2018 & 49,5 Triliun \\
\hline
\end{tabular}




\begin{tabular}{|c|c|}
\hline Tahun & Laba \\
\hline 2019 & 55,5 Triliun \\
\hline
\end{tabular}

Sumber : Otoritas Jasa Keuangan (2020)

Hal ini tentunya akan menarik perhatian dari investor, apalagi dalam praktiknya GCG (tata kelola perusahaan) diterapkan dengan baik maka nilai perusahaan akan semakin meningkat karena kepercayaan investor merupakan pondasi penting.

Dari itu peneliti tertarik meneliti terkait Nilai Perusahaan yang dipengaruhi oleh Good Corporate Governance (GCG) dan Profitabilitas pada Bank Swasta Devisa Nasional.

\section{KAJIAN PUSTAKA DAN PERUMUSAN HIPOTESIS}

\section{Akuntansi Keuangan}

Menurut Satria (2016:2) akuntansi keuangan adalah akuntansi yang bertujuan menghasilkan informasi keuangan suatu entitas yang berguna para pemangku kepentingan sebagai penerima dan pengguna laporan keuangan untuk ;

a) Pengambilan keputusan ekonomi,khususnya tentang investasi atau pinjaman

b) Pemahaman tentang posisi atau keadaan keuangan suatu unit usaha,susunan aset yaitu sumber ekonomi yang dimiliki,sumber pembelanjaan yaitu komposisi liabilitas dan ekuitas yang membelanjai aset tersebut

c) Pemahaman kinerja dan arus kas.

Untuk menghasilkan laporan keuangan yang baik akuntansi keuangan memiliki standar yaitu Standar Akuntansi Keuangan. Menurut Satria (2016:3) standar akuntansi keungan yaitu yaitu laporan keungan untuk tujuan umum dibuat untuk memenuhi kebutuhan sebagian besar pengguna laporan keuangan.Pengguna laporan keuangan beragam dengan memiliki kebutuhan yang berbeda. Oleh karena itu, untuk menyusun laporan keuangan ini diperlukan standar akuntansi keuangan.

Saat ini, hanya dua standar akuntansi yang banyak dijadikan referensi atau diadopsi di dunia yaitu international Financial Reporting Standar (IFRS) dan US Generally Accepted Accounting Principles (US-GAAP). IFRS disusun oleh international Accounting Standard Board (IASB) sedangkan US-GAAP disusun oleh Financial Accounting Standard Board (FASB).

Menurut Satria (2016:3) ada 4 pilar standar akuntansi keuangan:

1.) Standar Akuntansi Keuangan (SAK)

2.) Standar Akuntansi Keuangan Entitas Tanpa Akuntabilitas Publik ( SAK ETAP) 
3.) Standar Akuntansi Syariah

4.) Standar Akuntansi Pemerintah

\section{Bank}

Bank adalah badan usaha yang menghimpun dana dari masyarakat dalam bentuk simpanan dan menyalurkannya kepada masyarakat dalam bentuk kredit dan atau bentuk-bentuk lainnya dalam rangka meningkatkan taraf hidup rakyat banyak (Undang-undang Negara Republik Indonesia Nomor 10 Tahun 1998 Tanggal 10 November 1998 tentang perbankan). Dari definisi tersebut dapat disimpulkan bahwa ada tiga kegiatan pokok usaha yang dilakukan oleh perbankan yaitu menghimpun dana, menyalurkan dana, dan membrikan jasa perbankan lainnya.

\section{Good Corporate Governance}

Menurut FCGI (2001) pengertian Good Corporate Governance adalah seperangkat peraturan yang mengatur hubungan antara pemegang saham, pengurus (pengelola) perusahaan, pihak kreditur, pemerintah, karyawan serta para pemegang kepentingan intern dan esktern lainnya yang berkaitan dengan hak-hak dan kewajiban mereka atau dengan kata lain suatu sistem yang mengatur dan mengendalikan perusahaan. Secara teoritis, pelaksanaan good corporate governance dapat meningkatkan nilai perusahaan, dengan meningkatkan kinerja keuangan mereka, mengurangi risiko yang mungkin dilakukan oleh dewan komisaris dengan keputusan-keputusan yang menguntungkan diri sendiri dan umumnya good corporate governance dapat meningkatkan kepercayaan investor (Akal Muhammad dan Akal Andi, 2015:2). Maka dari definisi tersebut semakin baik tata kelola (good corporate governance) yang dilakukan oleh perusahaan, maka akan semakin meningkat penilaian investor pada perusahaan tersebut.

Dalam penelitian ini GCG di proksikan oleh Dewan Komisaris, Dewan Direksi, serta Komite Audit :

\section{Dewan komisaris}

Dalam suatu perusahaan lebih ditekankan pada fungsi monitoring dari implementasi kebijakan direksi. Peran komisaris ini diharapkan akan meminimalisir permasalahan agensi yang timbul antara dewan direksi dengan pemegang saham. Oleh karena itu dewan komisaris seharusnya dapat mengawasi kinerja dewan direksi sehingga kinerja yang dihasilkan sesuai dengan kepentingan pemegang saham. Dewan Komisaris memegang peranan penting dalam mengarahkan strategi dan mengawasi jalannya perusahaan serta 
memastikan bahwa para manajer benar-benar meningkatkan kinerja perusahaan sebagai bagian daripada pencapaian tujuan perusahaan. Secara umum dewan komisaris ditugaskan dan diberi tanggung jawab atas pengawasan kualitas informasi yang terkandung dalam laporan keuangan. Hal ini penting mengingat adanya kepentingan dari manajemen untuk melakukan manajemen laba yang berdampak pada berkurangnya kepercayaan investor. (Akal Muhammad dan Akal Andi, 2015:57).

\section{Dewan Direksi}

Dewan ini merupakan penanggung jawab utama dalamtingkat kesehatan dan keberhasilan perusahaan secara jangka panjang.Dewan direksi dalam suatu perusahaan akan menentukan kebijakan yang akan diambil atau strategi perusahaan tersebut secara jangka pendek maupun jangka panjang (Akal Muhammad dan Akal Andi, 2015:63).

\section{Komite Audit}

Komite audit yang bertanggung jawab untuk mengawasi laporan keuangan, mengawasi audit eksternal, dan mengamati sistem pengendalian internal (termasuk audit internal) dapat mengurangi sifat opportunistic manajemen yang melakukan manajemen laba (earnings management) dengan cara mengawasi laporan keuangan dan melakukan pengawasan pada audit eksternal (Akal Muhammad dan Akal Andi, 2015:71).

\section{Profitabilitas}

Profitabilitas adalah kemampuan suatu perusahaan untuk menghasilkan laba selama periode tertentu (Suleman dkk, 2019:12). Rasio ini digunakan untuk mengukur profit yang diperoleh dari modal-modal yang digunakan untuk memperoleh keuntungan.

Menurut Kasmir (2008:197), tujuan penggunaan profitabilitas bagi perusahaan maupun bagi pihak luar perusahaan adalah:

a. Untuk mengukur atau menghitung laba yang diperoleh perusahaan dalam satu periode tertentu,

b. Untuk menilai posisi laba perusahaan tahun sebelumnya dengan tahun sekarang

c. Untuk menilai perkembangan laba dari waktu ke waktu

d. Untuk mengukur produktifitas dari seluruh dana perusahaan yang digunakan baik modal sendiri 
e. Untuk mengukur produktivitas seluruh dana perusahaan yang digunakan baik modal pinjaman maupun modal sendiri.

f. Untuk mengukur produktivitas dari seluruh dana perusahaan yang digunakan.

\section{Nilai Perusahaan}

Mardiyanto (2009) menjelaskan bahwa "Nilai perusahaan adalah nilai sekarang dari serangkaian arus kas masuk yang akan dihasilkan perusahaan pada masa mendatang". Margaretha (2005) menjelaskan juga bahwa : "Nilai perusahaan yang sudah go public tercermin dalam harga pasar saham perusahaan. Sedangkan nilai perusahaan yang belum go public nilainya terealisasi apabila perusahaan akan dijual (total aktiva dan prospek perusahaan, risiko usaha, lingkungan usaha, dan lain-lain)" (Rahayu dan Sari, 2018).

Dari definisi diatas dapat disimpulkan bahwa nilai perusahaan adalah suatu kondisi yang sudah dicapai oleh perusahaan yang tercermin dalam harga saham.

Nilai perusahaan dapat diukur dengan suatu rasio yang disebut rasio penilaian. Sutrisno (2009:224) medefinisikan rasio penilaian adalah suatu rasio untuk mengukur kemampuan perusahaan dalam menciptakan nilai pada masyarakat (investor) atau pada para pemegang saham. Rasio penilaian memberikan informasi seberapa besar masyarakat menghargai perusahaan, sehingga masyarakat tertarik untuk membeli saham dengan harga yang lebih tinggi dibanding nilai bukunya.

Menurut Weston dan Copeland (2008:224) rasio penilaian terdiri dari: Price Earning Ratio (PER), Price to Book Value (PBV), Dan Rasio Tobin's Q.

\section{METODA PENELITIAN}

\section{Gambaran Singkat Objek Penelitian}

Objek yang digunakan dalam penelitian ini adalah Bank Swasta Devisa Nasional yang terdaftar di Bursa Efek Indonesia (BEI) yang di akses melalui website resmi BEI yaitu www.idx.co.id. Periode laporan keungan yang diperkirakan adalah 2015-2019

\section{Populasi dan Sampel Penelitian Populasi}

Populasi adalah wilayah generalisasi yang terdiri atas obyek/subyek yang mempunyai kuantitas dan karakteristik tertentu yang ditetapkan oleh peneliti untuk dipelajari dan kemudian ditarik kesimpulannya (Sugiyono, 2018). Populasi yang digunakan dalam penelitian ini adalah Bank Swasta Devisa Nasional yang terdaftar di Bursa Efek Indonesia (BEI) pada tahun 2015-2019. 


\section{Sampel}

Sampel adalah bagian dari jumlah dan karakteristik yang dimiliki oleh populasi tersebut (Sugiyono, 2018). Sampel dalam penelitian ini menggunakan metode Nonprobability Sampling yaitu teknik pengambilan sampel yang tidak memberikan peluan/kesempatan yang sama bagi setiap usur atau anggota populasi untuk dipilih menjadi sampel (Sugiyono, 2018).

Dengan teknik purposive sampling yaitu teknik penentuan sampel dengan pertimbangan tertentu (Sugiyono, 2018). Adapun kriteria-kriteria yang ditentukan dalam penelitian ini adalah sebagai berikut:

1. Bank Swasta Devisa Nasional yang terdaftar di BEI sebelum tanggal 1 Januari 2015.

2. Tidak mengalami kerugian selama 2015-2019

Berdasarkan kriteria tersebut, maka sampel dari penelitian ini dapat dilihat pada tabel berikut :

Tabel 2 Pemilihan Sampel

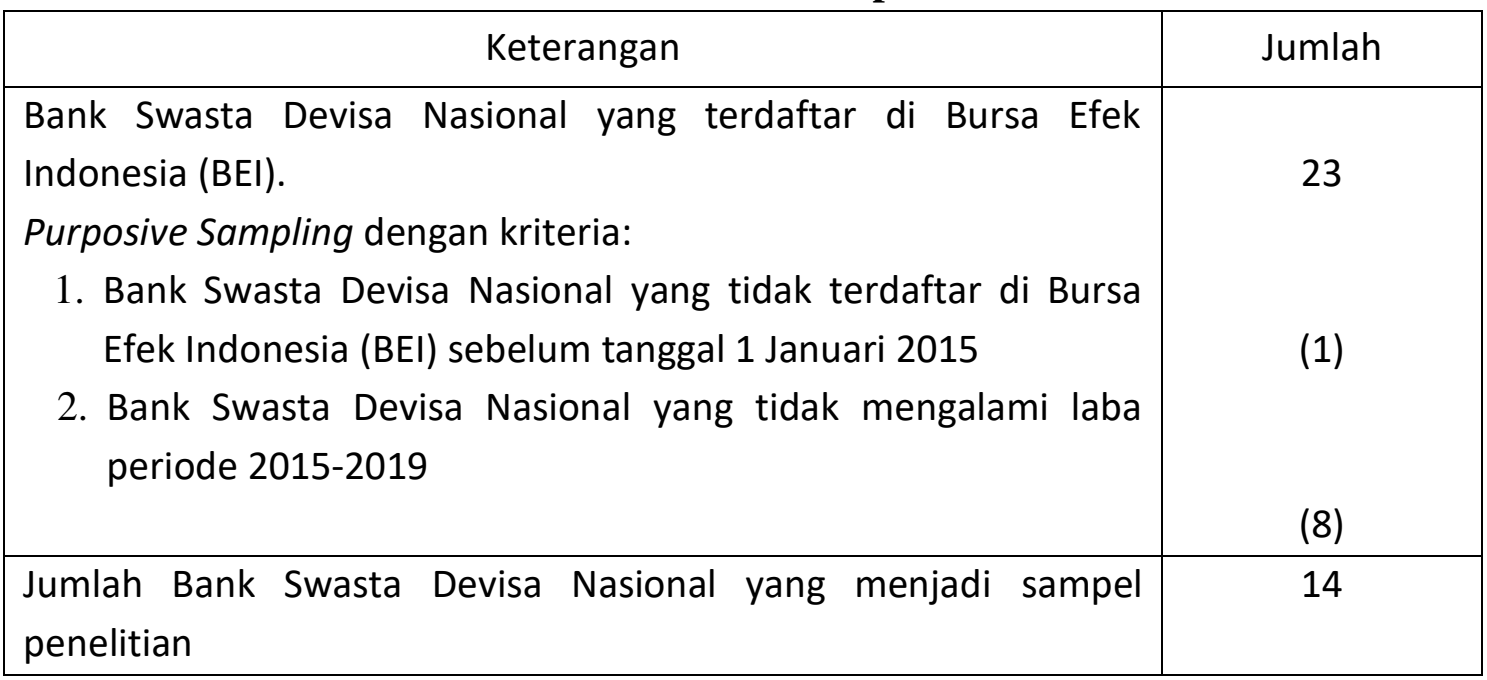

Sumber : Lampiran 1

Berdasarkan kriteria yang telah ditetapkan, maka terdapat 14 Bank Swasta

Devisa Nasional yang akan menjadi sampel dalam penelitian ini, berikut daftar Bank Swasta Devisa Nasional dalam penelitian ini adalah sebagai berikut:

Tabel 3 Daftar Sampel Penelitian

\begin{tabular}{|c|c|c|}
\hline No. & Kode Saham & Nama Bank \\
\hline 1 & AGRO & Bank Rakyat Indonesia Agro Niaga Tbk \\
\hline 2 & BBCA & Bank Central Asia Tbk \\
\hline 3 & BBKP & Bank Bukopin Tbk \\
\hline 4 & BBMD & Bank Mestika Dharma Tbk \\
\hline
\end{tabular}




\begin{tabular}{|c|c|c|}
\hline No. & Kode Saham & Nama Bank \\
\hline 5 & BDMN & Bank Danamon Indonesia Tbk \\
\hline 6 & BMAS & Bank Maspion Indonesia Tbk \\
\hline 7 & BNBA & Bank Bumi Arta Tbk \\
\hline 8 & BNGA & Bank CIMB Niaga Tbk \\
\hline 9 & BNII & Bank Maybank Indonesia Tbk \\
\hline 10 & BSIM & Bank Sinar Mas Tbk \\
\hline 11 & MEGA & Bank Mega Tbk \\
\hline 12 & NISP & Bank OCBC NISP Tbk \\
\hline 13 & PNBN & Bank Pan Indonesia Tbk \\
\hline 14 & SDRA & Bank Woori Saudara Indonesia Tbk \\
\hline
\end{tabular}

\section{Jenis Penelitian}

Jenis penelitian ini adalah penelitian kuantitatif yaitu metode penelitian yang berlandaskan pada filsafat positivism (konkrit dan bersifat sebab akibat), diguanakan untuk meneliti pada populasi atau sampel tertentu, pengumpulan menggunakan instrument penelitian, analisis data bersifat kuantitatif/statistic, dengan tujuan untuk menguji hipotesis yang telah ditetapkan (Sugiyono, 2018), dengan menggunakan sumber data sekunder yang diperoleh melalu website resmi Bursa Efek Indonesia (BEI) yaitu www.idx.co.id dimana data tersebut akan diolah lebih lanjut untuk memperoleh jawaban dari masalah yang muncul dalam penelitian ini.

\section{Identifikasi Variabel Penelitian}

Variabel Independen $(\mathbf{X})$

a. Good Corporate Governance

- Dewan Komisaris

- Dewan Direksi

- Komite Audit

b. Profitabilitas : Net Profit Margin (NPM)

Variabel Dependen (Y)

Nilai Perusahaan : Price Earning Ratio (PER)

Definisi Operasional Variabel Penelitian

Variabel Independen 
Menurut Sugiyono (2017:39) variabel bebas adalah variabel yang mempengaruhi atau menjadi sebab perubahannya atau timbulnya variabel terikat. Dalam penelitian ini variabel independen yang digunakan adalah dewan komisaris, dewan direksi, komite audit, dan profitabilitas.

\section{a. Dewan Komisaris}

Dewan komisari adalah jumlah total dewan komisaris, baik yang berasal dari internal perusahaan maupun dari eksternal perusahaan. Dewan komisaris diukur dengan menghitung jumlah anggota dewan komisaris pada suatu perusahaan.

\section{b. Dewan Direksi}

Dewan direksi adalah dewan yang bertugas mengawasi perusahaan dan memiliki peranan yang sangat vital dalam suau perusahaan. Dewan direksi diukur dengan menghitung jumlah anggota dewan direksi pada suatu perusahaan.

\section{c. Komite Audit}

Komite audit merupakan komite yang bertugas mengawasi dan mengelola pelaporan termasuk system pengendalian internal dan penerapan prinsip akuntansi yang diterima umum, serta mengawasi proses secara keseluruhan. Variabel komite audit diukur dengan melihat jumlah anggota komite audit yang dimiliki perusahaan.

\section{d. Profitabilitas}

Profitabilitas dalam penelitian ini diukur melalui net profit margin, dikarenakan NPM mampu memberikan informasi nilai profit yang paling baik dengan memasukkan unsur laba bersih setelah pajak dan hasil dari penjualan.

\section{Variabel Dependen}

Menurut Sugiyono (2017:80) mengemukakan bahwa variabel terikat sering disebut variabel output, kriteria, konsekuen. Variabel terikat merupakan variabel yang dipengaruhi atau yang menjadi akibat karena adanya variabel bebas. Dalam penelitian ini yang merupakan variabel terikat adalah nilai perusahaan. Nilai perusahaan adalah suatu kondisi tertentu yang telah dicapai oleh suatu perusahaan yang tercermin dalam harga pasar saham perusahaan tersebut. Dalam penelitian ini nilai perusahaan diukur dengan Price Earning Ratio yang menunjukkan perbandingan antara harga pasar saham dengan laba per lembar saham.

\section{Metode Analisis Data}




\section{Analisis Statistik Deskriptif}

Statistik deskriptif memberikan gambaran atau deskripsi suatu data yang dilihat dari nilai rata-rata (mean), standar deviasi, varian, maksimum, minimum,sum, range, kurtosis, dan skewnes. Statistik deskriptif dimaksudkan untuk memberikan gambaran mengenai distribusi dan perilaku data sampel tersebut (Ghozali, 2013:9)

\section{Uji Asumsi Klasik}

\section{Uji Normalitas}

Uji normalitas bertujuan untuk menguji apakah dalam model regresi variabel pengganggu atau residual memiliki distribusi normal. Dalam penelitian ini, peneliti menggunakan uji Kolmogrov-Smirnov untuk menentukan apakah data terdistribusi normal atau tidak. Jika nilai signifikansinya $\geq 0,05$ maka asumsi normalitas dapat terpenuhi, namun apabila lebih kecil dari 0,05 maka data tersebut tidak berdistribusi normal (Ghozali, 2013:160).

\section{Uji Multikolinieritas}

Menurut Ghozali (2013:105), uji multikolonieritas bertujuan untuk menguji apakah model regresi ditemukan adanya korelasi antar variabel bebas (independen). Model regresi yang baik seharusnya tidak terjadi korelasi antar variabel independen. Untuk mendeteksi ada tidaknya multikolinieritas dapat dilihat dari nilai tolerance value dan variance inflation factor (VIF).

\section{Uji Autokorelasi}

Uji autokorelasi bertujuan untuk menguji apakah dalam model regresi linier ada korelasi antara kesalahan pengganggu pada periode $t$ dengan kesalahan pengganggu pada periode $\mathrm{t}-1$ (sebelumnya). Jika terjadi korelasi, maka dinamakan ada problem autokorelasi. Autokorelasi muncul karena observasi ke observasi lainnya. Hal ini sering ditemukan pada data runtut waktu (time serries) karena "gangguan" pada seseorang individu/kelompok cenderung mempengaruhi "gangguan" pada individu/kelompok yang sama pada periode berikutnya (Ghozali, 2013:160).

\section{Uji Heteroskedastisitas}

Menurut Ghozali (2013:139), uji heteroskedastisitas bertujuan menguji apakah dalam model regresi terjadi ketidaksamaan variance dari residual satu pengamatan ke pengamatan yang lain. Jika variance dari residual satu pengamatan ke pengamatan lain tetap, maka disebut homoskedastisitas dan jika berbeda disebut heteroskedastisitas. Model regresi yang baik adalah yang homoskedastisitas. Salah satu cara untuk mendeteksi terjadinya heteroskedastisitas atau tidak adalah dengan melihat grafik plot antara nilai prediksi variabel dependen yaitu ZPRED dengan residualnya SRESID, deteksi ada tidaknya heteroskedastisitas dapat dilakukan dengan melihat ada tidaknya pola tertentu pada grafik scatterplot antara SRESID dan ZPREAD. Dasar analisis yang digunakan adalah: 
a. jika ada pola tertentu, seperti titik-titik yang ada membentuk pola tertentu yang teratur (bergelombang, melebar kemudian menyempit), maka mengidikasikan telah terjadi heteroskedastisitas.

b. jika tidak ada pola yang jelas, serta titik-titik menyebar diatas dan dibawah angka 0 pada sumbu Y, maka tidak terjadi heteroskedastisitas.

\section{Analisis Regresi Berganda}

Menurut Ghozali (2013:96), analisis regresi linier berganda yaitu analisis regresi yang mampu mengukur kekuatan hubungan antara variabel terikat (dependen) dengan variabel bebas (independen) yang lebih dari satu variabel. Model persamaan regresi linier berganda sebagai berikut :

$\mathrm{Y}=\mathrm{a}+\mathrm{b} 1 \mathrm{X} 1+\mathrm{b} 2 \mathrm{X} 2+\mathrm{b} 3 \mathrm{X} 3+\mathrm{b} 4 \mathrm{X} 4 \ldots \mathrm{e}$

Dimana :

Y : Nilai Perusahaan (PER)

a : Konstanta

X1 : Dewan Komisaris / DK

X2 : Dewan Direksi / DD

X3 : Komite Audit / KA

X4 : Profitabilitas / NPM

b1b2b3 : Koefisien Regresi

e : Error

\section{Uji Hipotesis}

\section{Uji Signifikan Parsial (Uji t)}

Uji t atau uji signifikan parameter individual menunjukkan ada atau tidak adanya pengaruh satu variabel independen secara individual terhadap variabel dependen dan seberapa besar pengaruhnya (Ghozali, 2013). Cara melakukan uji t adalah (Ghozali, 2013):

- Quick look jika total degree of freedom (df) adalah $\geq 20$ dan tingkat kepercayaan 5\% maka Ho (Hipotesis Nol) ditolak jika $\mathrm{t}>2$ (dalam nilai absolut) artinya jika Ha (Hipotesis alternatif) bahwa variabel independen secara individual mempengaruhi variabel dependen.

- Membandingkan nilai uji t dengan titik kritis menurut tabel: jika nilai thitung $>$ t tabel maka kita menerima Ha (Hipotesis alternatif) bahwa variabel independen secara individual mempengaruhi variabel dependen.

Rumus Uji t menurut Sugiyono (2017) sebagai berikut :

$$
t=\frac{b 1}{\mathrm{~S}(\mathrm{~b} 1)}
$$

Dimana :

t $\quad$ : hasil t hitung 
b1 : koefisien regresi linier dari variabel $\mathrm{X}$

S : standar eror dari faktor bebas

\section{Uji Signifikan Simultan (Uji F)}

Menurut Ghozali (2013) uji statistik F pada dasarnya menunjukkan apakah semua independent variable yang dimasukkan dalam model mempunyai pengaruh secara bersama-sama atau tidak terhadap dependent variable. Hipotesa yang akan diuji adalah sebagai brikut:

$\mathrm{H}_{0}$ : Tidak ada hubungan variabel antara satu independent variable terhadap dependent variable atau tidak signifikan. $\mathrm{H}_{\mathrm{a}}$ : Ada hubungan variabel antara satu independent variable terhadap dependent variable atau signifikan.

Rumus Uji F sebagai berikut :

$$
F=\frac{R^{2} / k}{\left(1-R^{2}\right) /(\mathrm{n}-\mathrm{k}-1)}
$$

Dimana :

$\mathrm{F} \quad: \mathrm{F}_{\text {hitung }}>$ selanjutnya dibandingkan dengan $\mathrm{F}_{\text {tabel }}$

R : koefisien korelasi berganda

$\mathrm{k} \quad$ : jumlah variabel bebas

n : jumlah sampel

\section{ANALISIS DAN PEMBAHASAN}

\section{Pengaruh Dewan Komisaris Terhadap Nilai Perusahaan}

Dewan Komisaris dalam suatu perusahaan berfungsi untuk mengarahkan strategi dan mengawasi jalannya perusahaan serta memastikan bahwa para manajer benarbenar meningkatkan kinerja perusahaan sebagai bagian daripada pencapaian tujuan perusahaan, sehingga dengan adanya dewan komisaris ini diharapkan nilai perusahaan akan meningkat melalui fungsi dari dewan komisaris tersebut. Variabel Dewan Komisaris pada Uji Parsial (Uji t) menunjukkan bahwa dewan komisaris tidak berpengaruh signifikan terhadap nilai perusahaan. Jumlah dewan komisaris pada objek penelitian ini bervariasi, apabila jumlah dewan komisaris dalam suatu perusahaan terlalu banyak maka tidak efektif karena dewan komisaris hanya sebagai pengawas tidak terjun langsung pada aktifitas operasional perusahaan.

Hasil penelitian ini sesuai dengan hasil penelitian Veronica (2013) dan Yusmaniarti dkk (2020) yang menyatakan bahwa dewan komisaris tidak berpengaruh signifikan terhadap nilai perusahaan. Sehingga hipotesis pertama dalam penelitian ini tidak terbukti. 


\section{Pengaruh Dewan Direksi Terhadap Nilai Perusahaan}

Dewan direksi merupakan penanggung jawab utama dalamtingkat kesehatan dan keberhasilan perusahaan secara jangka panjang, sehingga dewan direksi ini sangat penting bagi perusahaan. Kebijakan yang tepat dan kinerja dewan direksi yang maksimal tentunya akan menguntungkan perusahaan dan meningkatkan nilai perusahaan. Dewan direksi pada objek penelitian ini menunjukan tidak berpengaruh signifikan. Jumlah dewan direksi disetiap bank bervariasi. Jumlah dewan direksi yang terlalu banyak akan tidak efektif karena kebijakan yang akan diambil sangat sulit karena harus mempertimbangkan dari banyak sudut pandang dari banyak pihak, serta semakin banyak dewan direksi maka biaya yang dikeluarkan perusahaan akan semakin banyak pula sehingga akan mengurangi laba atau keuntungan perusahaan dannilai perusahaan akan menurun.

Hasil ini sesuai dengan hasil penelitian Sinaga (2018), Sondokan dkk (2019) Mawei dan Tulung (2019) yang menyatakan bahwa dewan direksi tidak berpengaruh signifikan terhadap nilai perusahaan.Sehingga hipotesis kedua dalam penelitian ini tidak terbukti.

\section{Pengaruh Komite Audit Terhadap Nilai Perusahaan}

Berdasarkan hasil uji parsial, dapat disimpulkan bahwa Komite Audit tidak berpengaruh signifikan terhadap nilai perusahaan sehingga hipotesis ketiga tidak terbukti. Hasil ini sesuai dengan Anggraini (2013), Veronica (2013) dan Agustina (2017) yang menyatakan bahwa komite audit tidak memiliki pengaruh signifikan terhadap nilai perusahaan.Kurang maksimalnya komite audit dalam menjalankan tugasnya membuat kualitas dari laporan keuangan yang dihasilkan kurang maksimal sehingga tidak berpengaruh terhadap nilai perusahaan

\section{Pengaruh Profitabilitas Terhadap Nilai Perusahaan}

Berdasarkan hasil uji parsial, dapat disimpulkan bahwa Profitabilitas tidak berpengaruh signifikan terhadap nilai perusahaan sehingga hipotesis keempat tidak terbukti. Hasil ini sesuai dengan penelitian Manopo dan Arie (2016), Santoso (2020) dan Intisari (2021) yang menyatakan bahwa profitabilitas yang di proksikan oleh Net Profit Margin (NPM) tidak berpengaruh signifikan terhadap nilai perusahaan. Dalam hal ini tingkat keuntungan yang didapatkan oleh perusahaan lebih kecil daripada penjualan maka hal tersebut akan mengurangi minat investor dalam menanamkan modalnya sehingga nilai perusahaan akan menurun. 


\section{Pengaruh Dewan Komisaris, Dewan Direksi, Komite Audit dan Profitabilitas Terhadap Nilai Perusahaan}

Berdasarkan hasil uji simultan menunjukkan bahwa semua variabel independen yaitu dewan komisaris, dewan direksi, komite audit dan profitabilitas berpengaruh signifikan terhadap nilai perusahaan pada Bank Swasta Devisa Nasional periode 2015-2019 sehingga hipotesis kelima terbukti. Hasil ini sesuai dengan hasil penelitian Sinaga (2018) dan Tamariz (2018) yang menyatakan bahwa dewan komisaris, dewan direksi, komite audit dan profitabilitas secara serentak mempengaruhi nilai perusahaan. Hal ini menunjukkan bahwa dewan komisaris, dewan direksi, komite audit dan profitabilitas dapat digunakan untuk memprediksi nilai perusahaan pada Bank Swasta Devisa Nasional yang terdaftar di Bursa Efek Indonesia (BEI) periode 2015-2019.

\section{KESIMPULAN}

Berdasarkan hasil analisis data tentang pengaruh dewan komisaris, dewan direksi, komite audit dan profitabilitas terhadap nilai perusahaan pada Bank Swasta Devisa Nasional periode 2015-2019, dapat disimpulkan bahwa :

1. Dewan komisaris tidak berpengaruh signifikan terhadap nilai perusahaan pada Bank Swasta Devisa Nasional periode 2015-2019. Hal ini menunjukkan bahwa adanya dewan komisaris tidak mempengaruhi tingkat nilai perusahaan. Tugas dewan komisaris hanya sebagai pengawas tidak terlibat langsung dalam aktivitas operasi.

2. Dewan Direksi tidak berpengaruh signifikan terhadap nilai perusahaan pada Bank Swasta Devisa Nasional periode 2015-2019. Hal ini menunjukkan bahwa dewan direksi belum mampu meningkkatkan nilai perusahaan.

3. Komite Audit tidak berpengaruh signifikan terhadap nilai perusahaan pada Bank Swasta Devisa Nasional periode 2015-2019. Hal ini menunjukkan bahwa komite audit dalam objek penelitian ini belum mampu meningkkatkan nilai perusahaan.

4. Profitabilitas tidak berpengaruh signifikan terhadap nilai perusahaan pada Bank Swasta Devisa Nasional periode 2015-2019. Hal ini menunjukkan bahwa profitabilitas pada objek penelitian ini belum mampu meningkatkan nilai perusahaan.

5. Pada Uji F menunjukkan bahwa secara simultan seluruh variabel independen yaitu dewan komisaris, dewan direksi, komite audit dan profitabilitas berpengaruh signifikan terhadap nilai perusahaan pada Bank Swasta Devisa Nasional periode 2015-2019. 


\section{SARAN}

Berdasarkan hasil analisis pembahasan dan simpulan pada penelitian ini, maka dapat disampaikan beberapa saran sebagai berikut :

1. Bagi Perusahaan

Dalam penelitian ini diketahui bahwa secara dewan komisaris, dewan direksi, komite audit dan profitabilitas tidak berpengaruh signifikan terhadap nilai perusahaan. Maka sebaiknya, perusahaan memaksimalkan kinerja dari dewan komisaris, dewan direksi serta komite audit agar dapat meningkatkan nilai perusahaan serta perusahaan juga perlu meningkat keuntungan (profit) agar investor tertarik untuk menanamkan modalnya.

2. Bagi Peniliti Selanjutnya

a. Sebaiknya menambah jumlah sampel penelitian dan menggunakan periode penelitian yang lebih lama untuk mengetahui konsistensi dari pengaruh variabel independen terhadap variabel dependen.

b. Dapat mengembangkan penelitian selanjutnya mengenai variabel independen lainnya yang memiliki pengaruh lebih besar terhadap nilai perusahaan. 


\section{DAFTAR PUSTAKA}

Agustina. 2017. Pengaruh Corporate Govrenance dan Variabel Keungan Terhadap Nilai perusahaan.Jurnal Bisnis dan Akuntansi. Volume 19 No 01.STIE Trisakti Jakarta. Jakarta.

Akal Muhammad, Andi Tentri Uleg Akal. 2015. Corporate Governance ( Konsep, Teori, dan Aplikasi di Beberapa Negara Asia). Maros. Pustaka Salewangan.

Anggraini. 2013. Pengaruh Good Corporate Govrenance Terhadap Nilai perusahaan Pada Perusahaan Textile, Garment yang Terdafar di Bursa Efek Indonesia (BEI) periode 2009-2012. Universitas Maritim Raja Ali Haji Tanjungpinang. Kepulauan Riau.

Ariefianto. 2010. Analisis Pengaruh Variance Of Earning Growth (VEG), Net Profit Margin, dan Debt Equity Ratio Terhadap Price Earning Ratio (PER) (Studi Empiris Pada Perusahaan Sektor Properti Tahun 2005-2008). UIN Syarif Hidayatullah. Jakarta.

Arikunto. 2010. Prosedur Penelitian Suatu Pendekatan Praktik. Jakarta. PT Rinerka Cipta.

Badan Pusat Statistik Jakarta Pusat. 2020. Berita Resmi Statisik. Jakarta Pusat: Badan Pusat Statistik.

Badruddien, Tieka Trikartika Gustyana, Andrieta Shintia Dewi. 2017. Pengaruh Good Governance, Laverage dan Ukuran Perusahaan Terhadap Nilai Perusahaan (Studi) Empiris Pada Sektor Industri Barang Konsumsi di Bursa Efek Indonesia Periode 2012-2015. E-Procceding Of Management. Volume 4 Nomor 3. Universitas Telkom. Bandung.

Brigham dan Houston, 2010. Dasar-dasar Manajemen Keuangan Buku 1. Jakarta. Salemba Empat.

Firdaus, Muhammad. 2019. Pengantar Manajemen Keuangan Teori dan Soal Jawab. Bandung. Alfabeta.

Febrianti. 2012. Faktor-faktor Yang Mempengaruhi Nilai Perusahaan Pada Industri Pertambangan di Bursa Efek Indonesia. Jurnal Bisnis dan Akuntansi. Volume 14 Nomor 2. STIE Trisakti. Jakarta.

Ghozali. 2013. Aplikasi Analisis Multivariate dengan Program IBM SPSS 21 Updat PLS Regresi. Badan Penerbit Universitas Diponegoro. 
Gultom, Agustina, Sri Widia Wijaya. 2013. Analisis Faktor-Faktor yang Mempengaruhi Nilai Perusahaan Pada Perusahaan Farmasi di Bursa Efek Indonesia. Jurnal Wira konmi Mikroskil. Volume 3 Nomor 01. STIE Mikroskil. Medan.

Hrp Putra, Saraswati. 2020. Bank dan Lembaga Keuangan Lainnya. Surabaya. CV. Jakad Media Publishing.

Intisari. 2021. Pengaruh Profitabilitas Terhadap Nilai Perusahaan Pada Perusahaan Manufaktur Sektor Makanan dan Minuman yang Terdaftar di Bursa Efek Indonesia. Universitas Muhammadiyah Palopo. Sulawesi Selatan.

Kasmir, 2014. Analisis Laporan Keuangan Pemerintah Daerah. Jakarta. Rajagrafindo Persada.

Manopo, Fitty Valdi Arie. 2016. Pengaruh Struktur Modal, Ukuran Perusahaan dan Profitabilitas Terhadap Nilai Perusahaan Otomotif yang Terdaftar di Bursa Efek Indonesia Periode 2011-2014. Jurnal EMBA. Volume 4 Nomor 2. Universitas Sam Ratulangi. Manado.

Marini, Nisha Marina. 2018. Pengaruh Good Corporate Governance Terhadap Nilai Perusahaan (Studi Empiris Pada Perusahaan Manufaktur yang Terdaftar di Bursa Efek Indonesia). Jurnal Humaniora. Volume 2 Nomor 2. UPBJJ Universitas Terbuka. Banda Aceh.

Otoritas Jasa Keuangan. 2020. Statistik Perbankan Indonesia. Volume 18 No 1. Departemen Perizinan dan Infomasi Perbankan. Jakarta.

Putri, Bambang Suprasto. 2016. Pengaruh Tanggung Jawab Sosial Perusahaan dan Mekanisme Tata Kelola Perusahaan Terhadap Nilai Perusahaan. E-Jurnal Akuntansi. Volume 15 Nomor 1. Universitas Udayana. Bali.

Rahayu, Bida Sari. 2018. Faktor-faktor Yang Mempengaruhi Nilai Perusahaan. Ikhraith-Humaniora. Volune 2 Nomor 2. Universitas Persada Indonesia. Jakarta.

Santoso. 2020. Pengaruh ROA, ROE, NPM dan Pengungkapan Corporate Social Responsibility Terhadap Nilai Perusahaan BUMN di Bursa Efek Indonesia Periode 2017-2019. STIE Indonesia Jakarta. Jakarta.

Satria. 2016. Akuntansi Keuangan 1. Universitas Malikussaleh. Aceh.

Setiawati, MelAliana Lim. 2018.Analisis P engaruh Profitabilitas, Ukuran Perusahaan, Laverage, dan Pengungkapan Sosial Terhadap Nilai Perusahaan Pada Perusahaan Manufaktur Yang Terdaftar di Bursa Efek Indonesia Periode 20112015. Jurnal Akuntansi. Volume 12 Nomor 1. Universitas Katolik Indonesia 
Atma Jaya. Jakarta.

Sinaga. 2018.pengaruh Corporate Social Responsibility, Dewan Direksi, Dewan Komisaris, Komite Audit, dan Profitabilitas Terhadap Nilai Perusahaan Studi pada Perusahaan Sektor Non-keuangan Yang Terdaftar di Bursa Efek Indonesia Tahun 2014-2016. Universitas Trisakti. Jakarta.

Sugiyanto, Tato Setiawan. 2019. Pengaruh Likuiditas Profitabilitas dan Good Corporate Governance Terhadap Nilai Perusahaan (Studi Kasus Oada Perusahaan Jasa Perbankan Yang Terdaftar di Bursa Efek Indonesia Pada Tahun 2014-2019. Prosiding Seminar Nasional Humanis. Universitas Pamulang. Banten.

Sugiyono. 2017. Metode Penelitian Kuantitatif, Kualitatif, dan R\&D. Bandung: Alfabeta

Sugiyono. 2018. Metode Penelitian Kuantitatif, Kualitatif, dan R\&D. Bandung. Alfabeta.

Suleman, Ratnawaty Marginingsih dan Isnurrini Hidayat Susilowati, 2019. Manajemen Keuangan. Universitas Bima Sarana Informatika. Jakarta.

Suryani, Hedryadi. 2015. Metode Riset Kuantitatif Teori dan Aplikasi pada Penelitian Bidang Manajemen dan Ekonomi Islam. Jakarta. Prenadamedia Group.

Susanto, Juniarti. 2013. Pengaruh Penerapan Good Corporate Governance (GCG) Pada Variabel Ukuran, Debt Ratio, dan Sektor Industri Terhadap Nilai Perusahaan. Bussines Accounting Review. Volume 1 Nomor 2. Universitas Kristen Petra. Surabaya.

Sutrisno, 2001. Manajemen Keuangan Teori, Konsep dan Aplikasi. Ekonisia UII. Yogyakarta.

Syafitri, Nila Firdausi Nuzula dan Ferina Nurlaily. 2018. Pengaruh Good Corporate Governance Terhadap Nilai Perusahaan (Studi Pada Perusahaan Industri Sub Sektor Logam dan Sejenisnya Yang Terdaftar di BEI Periode 2012-2016). Jurnal Administrasi Bisnis. Volume 56 Nomor 1. Universitas Brawijaya. Malang.

Syaifuddin. 2008. Manajemen Keuangan (Teori dan Aplikasi). Sulawesi Tenggara. Unhalu Press.

Tamariz. 2018. Pengaruh Kinerja Keungan dan Good Corporate Governance Terhadap Nilai Perusahaan (Studi Empiris pada Perusahaan Manufaktur Sektor Industri 
Dasar dan Kimia yang terdaftar di Bursa Efek Indonesia Tahun 2014-2016). Universitas Mercu Buana. Jakarta

Veronica. 2013. Pengaruh Good Corporate Governance, Corporate Social Responsibility \& Kinerja Keuangan Terhadap Nilai Perusahaan. Jurnal Dinamika Manajemen. Volume 4 Nomor 2. Universitas Gunadarma. Jakarta.

Wahyuni. 2020. Kinerja Sharia Conformity And Profitability Index dan Faktor Determinan. Surabaya. Scorpindo Media Pustaka.

Weston dan Copeland. 2001. Manajemen Keuangan. jilid 1. Alih bahasa Jaka Wasana, Kirbrandoko. Cetakan ketujuh. Penerbit Erlangga. Jakarta

Yusmaniarti, Febriyanti dan Budi Astuti. 2020. Pengaruh Penerapan Good Governance, Independensi auditor dan Kualitas Audit Terhadap Nilai Perusahaan. 2020. Jurnal Sains Manajemen dan Bisnis Indonesia. Volume 10 Nomor 1. Universitas Muhammadiyah Bengkulu. Bengkulu.

Zamzami, Aulia Fuad Rahman. 2013. Pengaruh Kinerja Keuangan Terhadap Price Earning Ratio (Studi Pada Perusahaan yang Tercatat Dalam Indeks LQ45). Universitas Brawijaya. Malang.

www.idx.co.id

www.sahamok.net 